\title{
$\mathrm{Na}$ rede de relações femininas um feminismo latente
}

\section{Bonecas Russas}

\section{CARDOSO, Eliana.}

São Paulo, Cia. das Letras, 2014, 97 p.

(c) $(1)$ Esta obra tem licença Creative Commons.

Eliana Cardoso estreou como romancista com o livro Bonecas Russas em 2014, narrativa que traz as marcas de um feminismo latente. Co- mo escritora, ela já era reconhecida na sua área de formação e ałuação profissional: economia. Mineira de Belo Horizonte, graduou-se na PUC do Rio de Janeiro, cursou o mestrado na UnB e o doutorado no Instituto de Tecnologia de Massachusetts (MIT). Trabalhou para o Banco Mundial na China, na Índia, no Paquistão, entre outros países da Ásia, e foi professora da Fundação Getúlio Vargas (FVG). Além desse romance, já publicou nove livros, vários capítulos de outros e mais de quarenta trabalhos em periódicos acadêmicos, todos na área de economia. Desde

1040 Estudos Feministas, Florianópolis, 23(3): 1023-1044, setembro-dezembro/2015 
2000, é colunista do periódico Valor Econômico, no qual assinava uma coluna sobre economia Há cerca de um ano, passou a assinar uma página quinzenal no caderno "EU \& Fim de Semana", publicando crônicas escritas em estilo fluente, claro, correto e, frequentemente, com muita ironia.

A escritora parece saber bem a importância do seu papel como formadora de opinião. Sempre preocupada com questões humanas, sociais e políticas, esses textos versam sobre assuntos que vão muito além da economia e nos possibilitam conhecer mais sobre seu vasto repertório de leituras literárias; seu conhecimento sobre artes plásticas, teatro, cinema, filosofia; suas vivências e experiências para além da cultura brasileira, bem como reconhecer seu posicionamento como feminista, entre outros aspectos. Eliana Cardoso, atenta aos costumes e cren-ças de seu tempo, faz a releitura de textos literários, críticos, filosóficos e psicanalíticos de todas as épocas e os usa como lentes para ver melhor a sua realidade circundante. Apenas para se ter uma ideia da diversidade de temas abordados, a autora já escreveu sobre religião e violência adultério, mentira e invenção como tradições seculares, insensatez humana, desejo sexual $e$ poder, sentido da morte, poluição e des-truição do planeta, entre outros.

Indagada, em uma entrevista na rádio FM cultura, sobre a intenção de levar adiante sua carreira de escritora, ela responde que esse val ser o primeiro de muitos outros livros, pois gosta muito de escrever ficção e acredita que "essas narrativas são uma maneira de pensar, entender e imaginar vidas diferentes daquelas que o autor viveu. Além de entender como as pessoas funcionam, interagem, se enxergam, se entendem através da memória e da reflexão sobre as suas ações".

Apesar de sua formação e longa ałuação profissional reconhecida na área de economia, Eliana Cardoso, no romance Bonecas Russas, também torna evidente sua intimidade com o campo literário, por meio do processo de citação de autores como Simões Lopes Neto, Graciliano Ramos, Joaquim Sabina, Roberto Bolaño, entre outros; ou pela alusão a obras como o poema Retrato, de Cecília Meireles; o romance A paixão segundo G.H., de Clarice Lispector, ao poema de W.B.Yeats: "A seus pés depositei meus sonhos. Pisa leve. Sobre eles você caminha" (p. 9). Já na forma como o sumário foi construído, bem como na escolha dos nomes de alguns personagens, há uma alusão ao poema "Quadrilha", de Carlos Drummond de Andrade.
O poema de Cecília Meireles, usado como epígrafe do romance, marca a hibridização dos gêneros discursivos, cada vez mais comum na construção dos textos literários contemporâneos; porém, o mais significativo aí são as pistas que a autora dá ao leitor nos versos do poema, para que ele não caia nas armadilhas das diversas vozes narrativas. O eu lírico na primeira estrofe parece alertar para o perigo da suposta onisciência de Rosália, colocando "ordem na narrativa" em primeira pessoa, no capítulo 4 :

Escreverás meu nome com todas as letras

Com todas as datas -

- e não serei eu. (p. 7)

Já na segunda estrofe, o eu lírico parece antecipar a voz de Leda, que alerta o leitor quanto aos atos de Lola:

Repetirás o que me ouviste

O que leste de mim, e mostrarás meu retrato - e nada disso serei eu. (p.7)

Em seu repertório de leituras literárias, representado na atuação de personagens intelectuais diversas, a escritora abrange não só a literatura brasileira, mexicana, ou irlandesa, como também recorre aos filósofos da Idade Média; faz uma digressão acerca da magna quaestio bizantina: "quantos anjos podem dançar no cabeça de um alfinete? Ou ainda de uma agulha?", e chega à contemporaneidade. Por exemplo, no capítulo em que a jornalista Miranda envia um e-mail para o editor, Jacinto, ela escreve uma bela página de crítica literária, na qual avalia obras e autores contemporâneos, mas também resgata outros intelectuais da belle époque brasileira.

Por meio do trabalho de citação, Eliana Cardoso nos revela um mapa de leituras que ficaram na sua memória, mostra-nos um panorama das contribuições da sua formação intelectual e, ao comentar o que leu, podemos, às vezes, perceber sua perspectiva crítica e estética. Concomitantemente, essa estratégia caracteriza as personagens da narrativa como intelectuais, cultas, mulheres emancipadas que estão inseridas em um contexto social muito distante do tempo em que as mulheres tinham que levantar bandeiras na luta pelo direito de trabalhar, de administrar seu próprio dinheiro, de expor livremente seu pensamento.

Tudo isso em 97 páginas, nas quais a escritura prende o leitor pela curiosidade de "quem é o próximo a falar?" ou "quem é essa personagem na rede de relações?"

A rede de relações tem como pontos fixos a vida de seis mulheres de uma mesma família 
que "saem umas das outras no labirinto das relações que as ligam", como afirma a própria autora em entrevista concedida à emissora de rádio Cultura FM. Francisca é mãe de Leda; Odete, casada com irmão de Francisca, é mãe de Lola; ambas com os casamentos desfeitos abandonam as filhas, e as duas pré-adolescentes vão formar uma nova configuração familiar com a tia Rosália (irmã de Francisca e cunhada de Odete). Além das cinco, no decorrer da narrativa, surge Miranda, enteada de Leda e rival de Lola.

Como o leitor pode ver, elas não "saem umas das outras" no sentido consanguíneo, mas são as heranças intelectuais, as vivências sociais, bem como o próprio ato de uma narrar a vida da outra que as fazem surgir uma da outra, como as bonecas russas.

Essa rede intrincada de relações familiares, permeada por personagens masculinos $e$ protagonizada por Leda e Lola, abriu margem para temas debatidos em outras mídias na atualidade como: a desestruturação familiar; traição e infidelidade, tanto masculina quanto feminina; novas configurações familiares; independência feminina; opção pela não maternidade tradicional - temas que, de uma forma ou outra, apontam para o início da dissolução do patriarcalismo - o grande vilão da história das mulheres.

A desestruturação familiar aparece tanto no círculo formado por Francisca, Roberto, Leda, Miranda, Joaquim e Celina quanto no formado por Odete, Afonso César, Lola, Modesto, Miranda e Jacinto. Rosália estabelece uma espécie de elo entre os dois círculos desfeitos, ao reconstruir um círculo afetivo familiar com as meninas que sobram desses casamentos desfeitos, formar uma nova configuração familiar, diferente das historicamente tradicionais e mais próxima das novas configurações familiares da contemporaneidade. Criando-as e educando-as como suas filhas, sem um companheiro, Rosália representa a afirmação da independência feminina.

Lá estava eu, a solteirona virgem, transformada em mãe das sobrinhas. Tenho responsabilidade e não me queixo. As meninas deram sentido à minha vida e hoje penso que sem elas eu teria vivido em vão. Lola e Leda. Primas-irmãs nascidas no mesmo ano e mesmo mês. (p. 23)

Lola e Leda crescem nesse novo lar como primas-irmãs, de modo que, depois de adultas, com seus próprios casamentos desfeitos, elas voltam a conviver, mas agora o grau de intimidade sugere sutilmente uma relação homoafetiva. Essa é, no entanto, uma questão não explorada pela escritora.
Concomitantemente, o enredo aponta para a independência financeira feminina, seja pela herança recebida, como é o caso de Rosália e Odete, seja como resultado de seu trabalho, como no caso de Francisca, Leda, Lola e Miranda. São todas mulheres burguesas e, com exceção de Odete, possuem boa formação acadêmica, intelectual e/ou artística, além de terem alcançado sucesso profissional.

De modo geral, os personagens masculinos tanto os maridos quanto os amantes - atuam como coadjuvantes, e mesmo os machistas, como Afonso César e Modesto, não conseguem exercer esse machismo. No máximo, continuam a ser cafajestes. O pai de Afonso César, Francisca e Rosália, um "banqueiro do sertão" no interior de Minas no início do século XX, é representado como beberrão que maltratava a mulher, mas vivia longo tempo ausente, viajando pelo sertão, e morreu cedo. Roberto parece nem se importar com a traição da esposa, apenas luta pela filha na separação com Francisca, mas a entrega à Tia Rosália, assim que se casa novamente, devido ao ciúme que a nova mulher tinha de Leda. Mon Cher, amante de Francisca, é apenas citado como "sedutor" quando jovem e "bêbado" bem mais tarde. Afonso César, infrator da lei, pai ausente, marido machista, acaba assassinado pela esposa adúltera. O professor de literatura, Cassiano Lobato, iniciador sexual de Leda, alto, musculoso, moreno de olhos verdes o que tinha de sedutor, tinha de insensível e de cafajeste também acaba assassinado. Joaquim Pinto Fernandes, o marido traído na noite de núpcias por Leda, porque adormeceu ao lado da filha do primeiro casamento, leva quase vinte anos para terminar o casamento com ela e se envolve com Celina. Modesto Mendonça de Bragança talvez seja o único a tentar impor seu machismo, além de Afonso César, e trava uma batalha verbal com Lola na noite de núpcias: "A rainha pensava que podia lhe dar ordens. Estava enganada. Ainda virgem e já não era menina. Sempre rejeitara os namorados. Com ele seria diferente" ( $p$. 50). Mas teve que negociar e ceder em outro aspecto para ter sua vontade feita. Assim como Joaquim, Modesto se envolve com outra mulher, e o casamento com Lola se dissolve depois de oito anos. Mais tarde, ele iria provar do próprio veneno da traição, quando Miranda o deixa para viver com Jacinto, tal qual a "Quadrilha" de Carlos Drummond de Andrade, sutilmente sugerida no sumário.

O que se evidencia como temática nessa narrativa é a naturalização da infidelidade conjugal, tanto feminina quanto masculina, 
resultando em casos de adultério, de traição, pois praticamente todos os casos são aceitos naturalmente, os casais se separam, e cada um recomeça sua vida em novo relacionamento ou não. Além disso, a traição não é só conjugal considerando o relacionamento de Miranda e Modesto -, uma vez que Miranda é sobrinha por afinidade da ex-mulher de Modesto.

O inusitado do caso amoroso de Tia Rosália com o Padre Mateus a ser revelado com tranquilidade para as sobrinhas/filhas surpreende o leitor - o qual, até então, pensava nessa tia como "a solteirona virgem, transformada em mãe das sobrinhas" (p. 23), a que "ficou para titia" porque "não arranjou casamento". A autora dá a entender que é um caso de muitos anos, vivido clandestinamente, o que levanta a antiga questão da hipocrisia de alguns representantes do clero católico, comprometido com o celibato e vivendo relacionamentos amorosos, denunciados na literatura desde o século XIX e que se perpetuam no século XXI. Ostentando a máscara da puritana, da mãe amorosa, por outro lado, Rosália é a única que vive o amor proibido até a velhice sem nunca ter que trair $0 \mathrm{com}$ panheiro.

Outro aspecto inovador que merece destaque, e diferencia a personagem, é que, no capítulo "Em que Rosália impõe ordem na narrativa" (p. 21), ela justifica sua atitude de impor essa ordem, justifica seus comentários, suas apreciações e juízos de valor sobre tudo e todas as outras personagens que vai mencionar, como se fosse uma narradora onisciente; no entanto, se manifesta em primeira pessoa.

Só leio romancistas que contam histórias em ordem cronológica. Longe de mim o prazer de quem se perde em tramas de narradores pouco confiáveis. Andei somando e me sobram motivos para condenar este livro que você agora tem em mãos. Cada mulher escreve o que pensa sem mencionar seu nome de família e revela pedaços da própria vida sem se preocupar com o bem-estar do leitor. Ele saberá ordenar alhos e bugalhos? Entender quem é quem? Apontar o verdadeiro criminoso, se cada uma das personagens se lembra dessa história como bem Ihe apraz? Acredito que, antes de ir em frente, o leitor tem o direito de saber de onde veio cada uma delas, por isso Ihe conto como tudo começou. (p. 21)

Enquanto revela ao leitor a origem de todos esses laços e desenlaces, Rosália vai construindo paulatinamente com o leitor a imagem de muIheres com personalidades tão diferentes, mas marcadas pela mesma sina: a falta de amor materno por um lado e os casamentos que acabam em infidelidade.

Francisca e Odete não demonstram sentir culpa por "abandonarem suas filhas", por não cumprirem com suas "obrigações maternas" e optarem pela sua liberdade/felicidade - cada qual seguindo com seus amantes, apesar das diferenças, um novo caminho. Francisca faz sua autorreflexão sobre a escolha feita e como lidou com a culpa:

Mãe abandona filha, eu via estampado nos jornais. O mundo inteiro sabendo que eu não podia amar. Que era igual a minha mãe. Seca. Estéril. Desnaturada. Isso tudo não faz sentido, você dirá. Nossa mãe não teve três filhos? Como pode ser estéril uma mãe de três filhos? Pode. Eu digo: pode. Uma deformação de caráter. Uma narcisista que vive apenas para o aplauso. Mas não. Não era isso que eu queria. O aplauso era apenas curativo. Eu queria o verdadeiro amor e achava que amor verdadeiro era o amor do homem, esquecida da existência do amor maternal. Às vezes eu gostava de Leda. Olhava para ela com peninha, mas o sentimento da indiferença vencia, e quando chegou a hora de escolher, escolhi. Entreguei a menina. Fui embora. Quando sentia culpa afastava a ideia, procurava distração. [...]. Nấo me arrependo de nada. (p. 19)

Ela reencontra a filha já adulta, mas não consegue estabelecer uma afetividade, sequer uma intimidade. De modo diverso, a escritora faz Odete desaparecer da narrativa, como personagem desprezada não só pelo abandono da filha, mas também em função da via marginal que optou seguir. Para Odete não é dado sequer a voz, sua história é contada por uma terceira pessoa, Rosália, e do ponto de vista dessa narradora, essa cunhada, que o marido deixava sozinha a maior parte do tempo,

[...] não era boa bisca. [...] Odete não ligava para a menina. Vai entender por que Odete tinha o mesmo comportamento de Francisca e de mamãe [...]. Como se Lola não existisse. Cunhada não é parente, é verdade. Só sei que nenhuma delas se importava com as filhas. Sina de família. Para completar, Odete se envolveu com o delegado de polícia do município vizinho à fazenda dela e de meu irmão. Um escândalo. Depois matou Afonso César, um crime que a polícia abafou. Fiquei com medo, negociei meu silêncio com Odete em troca da menina. (p. 22-23)

Cristina Stevens ${ }^{1}$ comenta a redefinição dos conceitos e da própria função de mãe/maternal/ maternidade na terceira fase do feminismo ainda 
em curso no ambiente pós-moderno em que estamos. Para ela, "a materni-dade é um dos pilares que sustentam o patriarca-do e também um componente importante da identidade feminina - a maternidade é, ao mesmo tempo um locus de poder e opressão, auto-realização e sacrifício, reverência e desvalorização." Ela ressalta ainda a importância dessa "ressignificação da mãe/do maternal, para que possamos nos livrar de sacralizações e fantasias que nós mulheres naturalizamos por tanto tempo." Com esse romance, Eliane Cardoso apresenta mais uma faceta dessa ressignifica-ção, não é a representação da mulher que opta pelo aborto porque o corpo lhe pertence, mas é a mulher que abandona a filha a quem nunca conseguiu amar - o que nos remete também ao "mito do amor materno", de Elisabeth Badinter.

Outro aspecto importante do romance é a estrutura circular em que os capítulos estão dispostos. O fechamento do último capítulo com a indagação de Lola para Leda: "E você? Ainda vai demorar?" (p. 97), no primeiro momento, cria uma expectativa de continuidade que o leitor só descobre quando fecha o livro e o reabre no primeiro capítulo, "Em que Leda aparece nua" (p. 9) para Lola, e essa circularidade narrativa remete o leitor ao círculo vicioso do desamor materno e suas consequências.

Os vinte capítulos são fragmentos de um todo, cujos títulos reiteram sempre um determinado tempo "Em que..." algum dos personagens toma a voz narrativa e conta mais um trecho da mesma história, ou o narrador onisciente retoma a voz. O encadeamento é feito pelo leitor. É preciso que ele monte o enredo como um mosaico, encaixando cada capítulo no seu devido lugar e no seu devido tempo. Mais do que isso, é preciso que o leitor participe da construção da narrativa, preenchendo as fissuras, as gretas entre as partes, entre os personagens que se autodescrevem ou descrevem alguém, entre o remetente e o destinatário de uma correspondência impressa ou digital. Nesse sentido, ao fazer a montagem, ao costurar os fragmentos, o leitor atua como coautor da narrativa.

Não é só a voz narrativa que muda de um capítulo para outro, mas também a inserção de outros gêneros textuais entre capítulos com um narrador onisciente e outros com um narrador em primeira pessoa expondo seu ponto de vista. A voz de Francisca se manifesta por carta impressa para Rosália; Miranda e Modesto começam seu relacionamento num "bate-papo virtual" (o capítulo é composto por vários fragmentos de falas de dias subsequentes ao longo de três meses tempo que levam para revelar sua verdadeira identidade - entre os trechos apenas breves marcas de tempo: "três meses mais tarde" (p. 60); trechos de um diário de Leda são lidos pela voz de Lola que também os comenta; a voz de Miranda se expressa por meio de longos e-mails enviados a Jacinto, seu amante; Leda escreve uma carta para Lola de Roma e assim por diante.

Apesar da riqueza de aspectos que representam literariamente a atual fase do feminismo a leitura do romance é leve, prazerosa e poética. Para uma análise, no entanto, recomendo fazêlo localizando a autora, a obra e seus temas no tempo e no espaço histórico, social e cultural.

\section{Nota}

1 Cristina STEVENS, 2005, p. 70.

\section{Referênclas}

BADINTER, Elisabeth. Um amor conquistado: o mito do amor materno. Tradução de Waltensir Dutra. Rio de Janeiro: Nova Fronteira, 1985.

STEVENS, Cristina. "Ressignificando a Maternidade: Psicanálise e Literatura". Gênero: revista do núcleo trandisciplinar de estudos de gênero, v.5, n.2, p. 65-79, ago./dez., 2005. Disponível em: <http://www.revistagenero.uff.br/ index.php/revistagenero/article/viewFile/385/ 289 >. Acesso em: 5 fev. 2015.

Risolete Maria Hellmann Instituto Federal de Santa Catarina

1044 Estudos Feministas, Florianópolis, 23(3): 1023-1044, setembro-dezembro/2015 